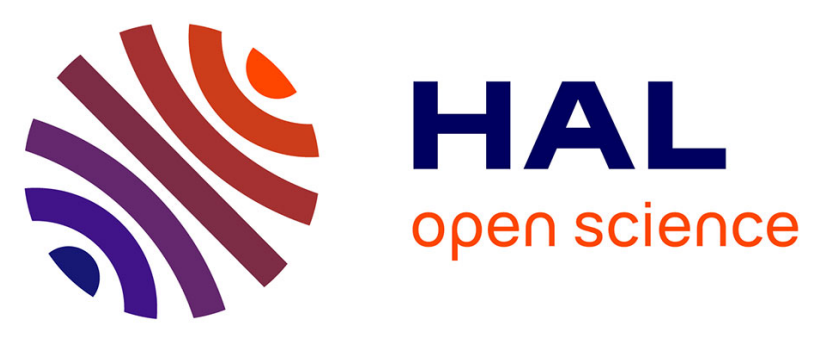

\title{
Iron Triflate Salts as Highly Active Catalysts for the Solvent-Free Oxidation of Cyclohexane
}

Pierre-adrien Payard, Yu-ting Zheng, Wen-juan Zhou, Lhoussain Khrouz, Laurent Bonneviot, Raphael Wischert, Laurence Grimaud, Marc Pera-titus

\section{- To cite this version:}

Pierre-adrien Payard, Yu-ting Zheng, Wen-juan Zhou, Lhoussain Khrouz, Laurent Bonneviot, et al.. Iron Triflate Salts as Highly Active Catalysts for the Solvent-Free Oxidation of Cyclohexane. European Journal of Organic Chemistry, 2020, 2020 (24), pp.3552-3559. 10.1002/ejoc.202000263 . hal02997698

\section{HAL Id: hal-02997698 \\ https://hal.sorbonne-universite.fr/hal-02997698}

Submitted on 10 Nov 2020

HAL is a multi-disciplinary open access archive for the deposit and dissemination of scientific research documents, whether they are published or not. The documents may come from teaching and research institutions in France or abroad, or from public or private research centers.
L'archive ouverte pluridisciplinaire HAL, est destinée au dépôt et à la diffusion de documents scientifiques de niveau recherche, publiés ou non, émanant des établissements d'enseignement et de recherche français ou étrangers, des laboratoires publics ou privés. 


\title{
Iron Triflate Salts as Highly Active Catalysts for the Solvent-Free Oxidation of Cyclohexane
}

\author{
Pierre-Adrien Payard, [a,b] Yu-Ting Zheng, [a] Wen-Juan Zhou,[a]* Lhoussain Khrouz,[c] Laurent Bonneviot, \\ [c] Raphael Wischert, [a] Laurence Grimaud, ${ }^{[b]}$ Marc Pera-Titus[a]*
}

\begin{abstract}
Among a series of iron salts, iron triflates revealed as highly active catalysts for the oxidation of cyclohexane by $t$-butyl hydroperoxide into cyclohexanol and cyclohexanone with initial turnover frequencies higher than $10,000 \mathrm{~h}^{-1}$. The structure of the iron complexes under reaction conditions was studied by combining electron paramagnetic resonance (EPR) spectroscopy and DFT calculations. The coordination of the catalytic iron center readily evolved in the presence of the reaction products, leading ultimately to its deactivation. Iron and organic superoxo intermediates were identified as plausible active species allowing to rationalize the high activity of iron ligated by highly-delocalized counter-anions.
\end{abstract}

\section{Introduction}

The oxidation of cyclohexane $(\mathrm{CyH})$ to cyclohexanol $(\mathrm{CyOH})$ and cyclohexanone (CyONE), also known as $\mathrm{KA}$ oil, is a well-known industrial process for the production of adipic acid (AA).[1] This process comprises two consecutive oxidation steps (Scheme 1): (i) non-catalytic autoxidation of $\mathrm{CyH}$ by $\mathrm{O}_{2}$ yielding cyclohexyl hydroperoxide (CyHP), and (ii) deperoxidation of CyHP to KA oil catalyzed by a transition metal, typically a homogeneous cobalt catalyst.[2] The process is conducted at very low $\mathrm{CyH}$ conversion $(\sim 5 \%)$ with a CyHP selectivity typically of $60-70 \%$ in the first step. ${ }^{[3]}$ The industrial challenge is to increase the catalytic activity for KA formation while keeping the CyHP concentration as low as possible using a clean and safe route. In this view, a fast and selective catalytic pathway using a non-toxic metal would be desirable.

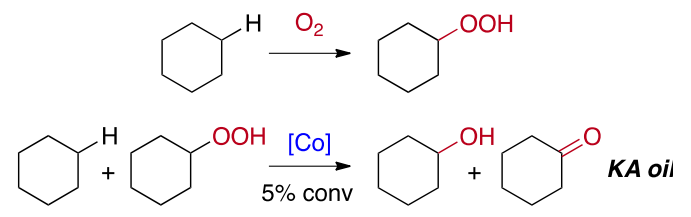

Scheme 1. Industrial process for the oxidation to $\mathrm{CyH}$ to $\mathrm{KA}$ oil.

[a] Dr Pierre-Adrien Payard, Dr Yu-Ting Zheng, Dr Wenjuan Zhou, Dr Raphael Wischert, Dr Marc Pera-Titus

Eco-Efficient Products and Processes Laboratory (E2P2L), UMI 3464 CNRS - Solvay, 3966 Jin Du Road, Xin Zhuang Ind Zone, 201108 Shanghai, China.

E-mail: wenjuan.zhou@solvay.com, marc.pera-titus-ext@solvay.com

[b] Dr Pierre-Adrien Payard, Dr Laurence Grimaud

Laboratoire des Biomolécules, LBM, Département de Chimie, École Normale Supérieure, PSL University, Sorbonne Université, CNRS, 75005 Paris, France.

[c] Mr Lhoussain Khrouz, Prof Laurent Bonneviot Univ Lyon, ENS de Lyon, CNRS UMR 5182, Université Claude Bernard Lyon 1, Laboratoire de Chimie, F69342, Lyon, France.

Supporting information for this article is given via a link at the end of the document.
High-valent iron-oxo complexes (e.g., cytochrome P450) are known to efficiently catalyze oxidation reactions in living systems. ${ }^{[4]}$ Iron-oxo systems have been extended to non-heme bio-inspired catalysts based on iron centers, [5] and to mononuclear iron complexes.[6] The most studied and simplest non-heme iron system relies on the so-called Fenton reagent consisting of an aqueous solution of hydrogen peroxide and an iron salt.[7] This reagent has been widely used in the total oxidation of organic pollutants in liquid waste treatment, as it generates very active and non-selective $\mathrm{OH}^{\circ}$ radicals. ${ }^{[8]}$ The search for high selectivity in partial oxidation reactions has led to the development of alternative catalytic systems comprising highly oxidized iron-oxo intermediates (IV or V).[9] To stabilize high-valent iron intermediates, a ligand is generally used.[10]

A well-known application of iron complexes for $\mathrm{CyH}$ oxidation relies on the pioneering work of Barton, using an iron catalyst combined with metallic zinc and oxygen as oxidant.[11] This chemistry was improved by replacing $\mathrm{Fe}(\mathrm{II}) / \mathrm{Zn} / \mathrm{O}_{2}$ by $\mathrm{Fe}(\mathrm{II}) /$ superoxide. Using an analogous system based on $\mathrm{Fe}(\mathrm{III}) / \mathrm{TBHP}$ ( TBHP = t-butyl hydroperoxide) based on (tris(trimethylacetate))iron(III) [Fe(tma) $)_{3}$ and (tris $(1,1,1,2,2,3,3$ heptafluoro-7,7-dimethyl-4,6-octanodionate)iron(III) [Fe(fod $\left.)_{3}\right]$, Schuchardt et al reported a selectivity of $91 \%$ at $11 \%$ conversion for $\mathrm{CyH}$ oxidation. ${ }^{[12]}$ However, the product (AA) deactivated the active iron centers.

Recently, iron triflates, i.e. Fell(OTf) 2 and Felll(OTf) ${ }_{3}$, have been reported as active catalysts in low-coordinating solvents for a variety of Lewis-acid catalyzed reactions. ${ }^{[13]}$ Typical examples include imination of sulfoxides, ${ }^{[14]}$ aziridination of enol silyl ethers, [15] hydroaddition to unsaturated C-C bonds, [16] etherification and transetherification of alcohols, ${ }^{[17]}$ and glycosylation of sugar derivatives.[18] Despite the potential of iron triflates for $\mathrm{C}-\mathrm{H}$ activation in $\mathrm{C}-\mathrm{N},{ }^{[19]} \mathrm{C}-\mathrm{C},{ }^{[20]}$ and $\mathrm{C}-\mathrm{X}(\mathrm{X}=\mathrm{F}, \mathrm{Cl}$, I) ${ }^{[21]}$ coupling reactions, few reports are available on oxidation reactions. [5b,22]

Herein we report an unprecedented high catalytic activity of $\mathrm{Fe}^{\text {III }}(\mathrm{OTf})_{3}$ for the oxidation of neat $\mathrm{CyH}$ towards $\mathrm{CyOH}$ and CyONE (KA oil) using TBHP as oxidant (Scheme 2). Fell'(OTf) behaved as precursor of the active iron species for $\mathrm{CyH}$ oxidation. We provide detailed insight into the structure of the catalyst under reaction conditions by combining electron paramagnetic resonance (EPR) and DFT calculations.

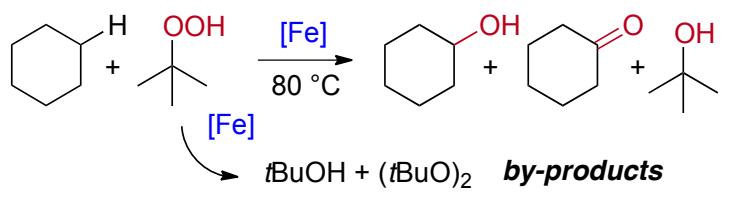

Scheme 2. Oxidation of $\mathrm{CyH}$ to $\mathrm{KA}$ oil catalyzed by Fe catalysts. 
Table 1. CyH and TBHP conversion, $\mathrm{KA}$ selectivity and yield, $\mathrm{A} / \mathrm{K}$ molar ratio and TOFs as a function of the catalyst at $0.14 \mathrm{mM} \mathrm{Fe}{ }^{\text {III }}(\mathrm{OTf})_{3}(10 \mathrm{ppm} \mathrm{Fe})^{[a]}$

\begin{tabular}{|c|c|c|c|c|c|c|}
\hline Complex[b] & $\begin{array}{l}\text { CyH conv } \\
(\%)\end{array}$ & $\begin{array}{l}\text { TBHP } \\
\text { conv } \\
(\%)\end{array}$ & $\begin{array}{l}\text { KA sel } \\
(\%)\end{array}$ & $\begin{array}{l}\mathrm{KA} \\
\text { yield } \\
(\%)\end{array}$ & $\mathrm{A} / \mathrm{K}$ & TON \\
\hline 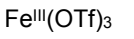 & 1.9 & 73 & 35 & 25 & 6.4 & 1175 \\
\hline $\mathrm{Fe}^{\| l}(\mathrm{OTf})_{2}$ & 1.2 & 74 & 21 & 16 & 3.3 & 765 \\
\hline $\mathrm{Fe}^{\prime \prime \prime}\left(\mathrm{NTf}_{2}\right)_{3}$ & 1.0 & 69 & 23 & 16 & 3.1 & 651 \\
\hline Cl-Fe"l'TPP & 0.9 & 69 & 17 & 12 & 2.8 & 574 \\
\hline $\mathrm{Fe}^{\prime \prime \prime}(\mathrm{OTs})_{3}$ & 0.7 & 57 & 19 & 11 & 3.3 & 455 \\
\hline $\mathrm{Fe}^{111} \mathrm{Cl}_{3}$ & 0.4 & 30 & 16 & 5 & 5.5 & 231 \\
\hline
\end{tabular}

[a] Reaction conditions: $80^{\circ} \mathrm{C}$, CyH $(4.0 \mathrm{~g})$ containing TBHP $(7.5 \mathrm{wt} \%, 3.3 \mathrm{mmol}), 0.14$ mmol catalyst (10 ppm Fe), 60 min. [b] OTf: $\mathrm{SO}_{2} \mathrm{CF}_{3}, \quad \mathrm{NTf}_{2}: \mathrm{N}\left(\mathrm{SO}_{2} \mathrm{CF}_{3}\right)_{2}$, TPP tetraphenylporphyrine, OTs: $\mathrm{OSO}_{2} \mathrm{To}$

Table 2. $\mathrm{CyH}$ and TBHP conversion, $\mathrm{KA}$ selectivity and yield, $\mathrm{A} / \mathrm{K}$ molar ratio and TON as a function of the Fe"lI(OTf) 3 concentration ${ }^{[a]}$

\begin{tabular}{lllllll}
\hline $\begin{array}{l}\mathrm{C}_{\mathrm{Fe}} \\
(\mathrm{mM})\end{array}$ & $\begin{array}{l}\text { CyH conv } \\
(\%)\end{array}$ & $\begin{array}{l}\text { TBHP } \\
\text { conv }(\%)\end{array}$ & $\begin{array}{l}\text { KA sel } \\
(\%)\end{array}$ & $\begin{array}{l}\text { KA } \\
\text { yield } \\
(\%)\end{array}$ & A/K & TON \\
\hline 0.014 & 0.43 & 6.6 & 86 & 5.7 & 82 & 2658 \\
0.070 & 1.4 & 52 & 34 & 18 & 8.6 & 1670 \\
0.14 & 1.8 & 81 & 29 & 24 & 4.0 & 1140 \\
0.56 & 2.1 & 88 & 30 & 27 & 2.3 & 310 \\
1.95 & 2.3 & 96 & 32 & 30 & 2.1 & 101
\end{tabular}

[a] Reaction conditions: $80^{\circ} \mathrm{C}, \mathrm{CyH}(4.0 \mathrm{~g})$ containing TBHP $(7.5 \mathrm{wt} \%), 60 \mathrm{~min}$

Table 3. $\mathrm{CyH}$ and TBHP conversion, $\mathrm{KA}$ selectivity and yield, $\mathrm{A} / \mathrm{K}$ molar ratio and TON as a function of the temperature[a]

\begin{tabular}{lllllll}
\hline $\begin{array}{l}\mathrm{T} \\
\left({ }^{\circ} \mathrm{C}\right)\end{array}$ & $\begin{array}{l}\text { CyH conv } \\
(\%)\end{array}$ & $\begin{array}{l}\text { TBHP } \\
\text { conv }(\%)\end{array}$ & $\begin{array}{l}\text { KA sel } \\
(\%)\end{array}$ & $\begin{array}{l}\mathrm{KA} \\
\text { yield } \\
(\%)\end{array}$ & A/K & TON \\
\hline 40 & 0.4 & 30 & 16 & 5 & 5.5 & 231 \\
45 & 0.7 & 57 & 19 & 11 & 3.3 & 455 \\
50 & 0.9 & 69 & 17 & 12 & 2.8 & 574 \\
55 & 1.0 & 69 & 23 & 16 & 3.1 & 651 \\
60 & 1.2 & 74 & 21 & 16 & 3.3 & 765 \\
65 & 1.3 & 78 & 25 & 19 & 3.6 & 811 \\
70 & 1.5 & 80 & 28 & 22 & 3.6 & 922 \\
80 & 1.8 & 81 & 29 & 24 & 4.0 & 1140 \\
\hline
\end{tabular}

[a] Reaction conditions: $80^{\circ} \mathrm{C}, \mathrm{CyH}(4.0 \mathrm{~g})$ containing TBHP $(7.5 \mathrm{wt} \%), 60 \mathrm{~min}, 0.14 \mathrm{mM}$ $\mathrm{Fe}^{\text {llI }}(\mathrm{OTf})_{3}(10 \mathrm{ppm} \mathrm{Fe}), 60 \mathrm{~min}$

\section{Results and Discussion}

\section{Definition of the catalyst performance metrics}

The catalytic performance of the different $\mathrm{Fe}$ complexes was primarily characterized in terms of the TBHP conversion, KA selectivity and KA yield with respect to TBHP, as well as by the turnover frequency at time $t=0\left(\mathrm{TOF}_{0}\right)$ and the turnover number (TON) at 60 min. [23] More details on the reaction metrics can be found in the SI (Experimental section, section 1.3).

\section{CyH oxidation using TBHP as oxidizing agent}

Screening of Fe complexes
The catalytic activity of a series of $\mathrm{Fe}$ complexes was first investigated using $\mathrm{CyH}$ as reactant and TBHP as an oxidant (7.5 wt $\%$ or $0.65 \mathrm{mM}$ in $\mathrm{CyH}$, see $\mathrm{SI}$ for preparation, section 1.2) at $80{ }^{\circ} \mathrm{C}$ under reflux. For comparison, a porphyrin based $\mathrm{Fe}$ salt (Cl-Fe-TPP) was chosen as reference catalyst, and its reactivity was compared to that of $\mathrm{Fe}(\mathrm{II})$ and $\mathrm{Fe}(\mathrm{III})$ salts, i.e. Fell $(\mathrm{OTf})_{2}$,

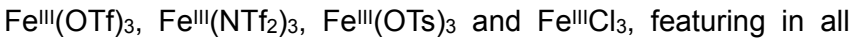
cases a highly delocalized, poorly coordinating, counter anion.

The products and reactants were analyzed by GC (see SI, section 1.3 for detailed method) after $60 \mathrm{~min}$ (Table 1). Among the different Fe complexes, the least soluble in CyH is Fe'll(OTf) with a solubility of $0.59 \mathrm{mM}$ and $0.24 \mathrm{mM}$ at $20^{\circ} \mathrm{C}$ and $80{ }^{\circ} \mathrm{C}$, respectively (see $\mathrm{SI}$, section 1.4 for solubility measurements). In light of these results, a Fe concentration of $0.14 \mathrm{mM}(10 \mathrm{ppm}$ $\mathrm{Fe}$ ) was chosen to compare the catalytic activity of the complexes. The most active complexes for $\mathrm{CyH}$ oxidation also appear to be the most selective towards KA oil (entries 1-3) by minimizing undesired TBHP disproportionation to t-butyl alcohol and $\mathrm{O}_{2}$, and the formation of ${ }^{\mathrm{B}} \mathrm{BuO}-\mathrm{O} \mathrm{B} \mathrm{Bu}$ (Scheme 2). Note that tBuO-OCy was not detected, opposing previous studies encompassing $\mathrm{CyH}$ oxidation by TBHP using solvents (e.g,, acetonitrile) under dilute conditions. [24]

Among the different $\mathrm{Fe}$ complexes, Fell( $(\mathrm{OTf})_{3}$ exhibits the highest TBHP conversion and KA yield with values of $73 \%$ and $25 \%$, respectively. Also, the TON after $60 \mathrm{~min}$ is the highest with a value of ca. 1200. Surprisingly, both triflate and triflimide Fe salts perform much better than the porphyrin based Fe salt. The TON decreases in the order: Felll $(\mathrm{OTf})_{3}>\mathrm{Fe}^{l l}(\mathrm{OTf})_{2}>\mathrm{Fell}^{l l}\left(\mathrm{NTf}_{2}\right)_{3}$ $>\mathrm{Cl}$-FelllTPP $>\mathrm{Fe}^{\text {Ill' }}(\mathrm{OTs})_{3}>\mathrm{Fe}^{\text {llI }} \mathrm{Cl}_{3}$. Noteworthy, at the reaction conditions tested, Fell(OTf $)_{2}$ is slightly less active than $\mathrm{Fe}^{\text {Ill }}(\mathrm{OTf})_{3}$. However, Felll(OTf) $)_{3}$ shows a higher alcohol-toketone molar ratio $(\mathrm{A} / \mathrm{K})(6.4$ vs. 3.3).

\section{Effect of the $\mathrm{Fe}^{\prime \prime \prime}(\mathrm{OTf})_{3}$ concentration}

The catalytic properties of Fell'(OTf) $)_{3}$ were then explored at variable catalyst concentration in the range 0.014-1.95 mM (1-140 ppm Fe) (Table 2). Increasing the Fe concentration from $0.014 \mathrm{mM}$ (1 ppm Fe) to $0.56 \mathrm{mM}$ (40 ppm Fe) clearly promotes the $\mathrm{CyH}$ and TBHP conversion, but at the expense of the TON. This observation suggests that a high catalyst concentration (especially $>0.14 \mathrm{mM}$ or $10 \mathrm{ppm} \mathrm{Fe}$ ) does not enhance the catalytic activity. The highest TON at $60 \mathrm{~min}$ (about 2600) is achieved at very low KA yield $(5.7 \%)$ and at the lowest $\mathrm{Fe}^{\text {III }}(\mathrm{OTf})_{3}$ concentration $(0.014 \mathrm{mM})$. Besides, the $\mathrm{A} / \mathrm{K}$ molar ratio declines at higher Fe concentration from 82 at $0.014 \mathrm{mM}$ to 4.0 at $0.14 \mathrm{mM}$, suggesting that CyONE is a secondary oxidation product of $\mathrm{CyH}$.

\section{Effect of the reaction temperature}

The effect of the temperature was studied in the range 40-100 ${ }^{\circ} \mathrm{C}$ using $0.14 \mathrm{mM} \mathrm{Fe}{ }^{\text {llI }}(\mathrm{OTf})_{3}$ (10 ppm Fe) (Table 3). CyH oxidation is enhanced at higher temperature at the expense of disproportionation into $t$-butyl alcohol and $\mathrm{O}_{2}$, with $\mathrm{KA}$ oil being enriched in $\mathrm{CyOH}$. In parallel, the $\mathrm{A} / \mathrm{K}$ molar ratio decreases with the temperature from an initial value of 5.5 at $40{ }^{\circ} \mathrm{C}$ to $2.8-4.0$ in the temperature range $45-80{ }^{\circ} \mathrm{C}$.

\section{Reactant and product evolution during the reaction}

The reaction kinetics was measured at different temperatures during the first $20 \mathrm{~min}$ of reaction using $\mathrm{Fe}^{\text {III }}(\mathrm{OTf})_{3}$ and Fell' $\left(\mathrm{NTf}_{2}\right)_{3}$ as catalysts (Figure 1). For both catalysts, KA oil formation proceeds fast during the first $15 \mathrm{~min}$ with a decrease of the $\mathrm{A} / \mathrm{K}$ molar ratio, but stabilizes after 10-20 min for temperatures higher than $50{ }^{\circ} \mathrm{C}$. At first sight, this observation 
suggests catalyst deactivation, which could be caused either by the reaction products, or from by-products. Indeed, traces of $A A$ were detected, which combined with water are known to deactivate Fe centers. ${ }^{[5 c, 12]}$ To gain more insight into the underlying mechanism of $\mathrm{Fe}$ deactivation, $\mathrm{CyOH}, \mathrm{CyONE}$ and $\mathrm{AA}$ were added to the reaction media in the beginning of the reaction. While $\mathrm{CyOH}$ or CyONE only exert a slight effect, $\mathrm{AA}$ strongly lowers the KA yield, thus confirming the deactivating role of AA (Table 4).
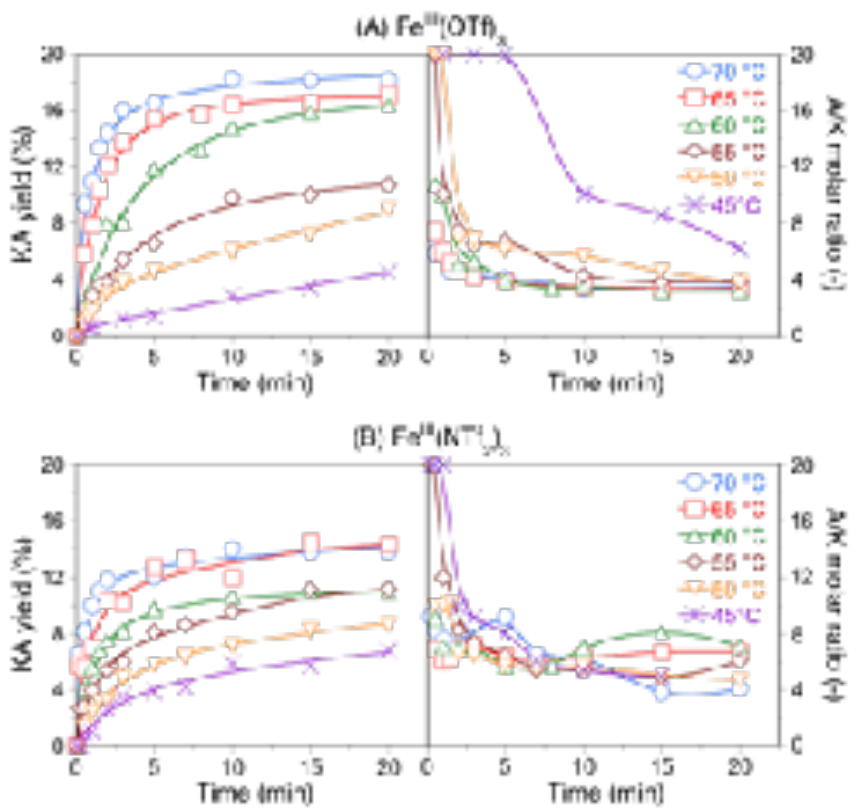

Figure 1. Time-evolution of $\mathrm{KA}$ yield and $\mathrm{A} / \mathrm{K}$ molar ratio in $\mathrm{CyH}$ oxidation catalyzed by $(\mathrm{A}) \mathrm{Fe}^{\mathrm{III}}(\mathrm{OTf})_{3}$ and $(\mathrm{B}) \mathrm{Fe}^{\mathrm{IlI}}\left(\mathrm{NTf}_{2}\right)_{3}$ with TBHP as oxidant. Reaction conditions: $45-70{ }^{\circ} \mathrm{C}, 0.14 \mathrm{mM}$ catalyst $(10 \mathrm{ppm} \mathrm{Fe}), 4 \mathrm{~g}$ of CyH containing 7.5 wt\% (3.3 mmol) TBHP, 0-20 min.

Table 4. Evolution of the KA yield upon addition of $\mathrm{CyOH}$, CyONE and $\mathrm{AA}$ before the reaction. [a] The concentration of products was adjusted to magnify the effect on the KA yield.

\begin{tabular}{clcc}
\hline \multicolumn{1}{c}{ Additive } & $\begin{array}{c}\text { KA } \\
\text { Yield } \\
\%\end{array}$ & $\begin{array}{c}\Delta \text { KA } \\
\text { Yield \% }\end{array}$ \\
\hline 0 & - & 25 & 0 \\
1 & CyOH $(0.212 \mathrm{mM})$ & 28 & +3 \\
2 & CyONE $(0.084 \mathrm{mM})$ & 21 & -4 \\
3 & AА $(0.095 \mathrm{mM})$ & 16 & -9 \\
4 & $\mathrm{CyOH}(0.198 \mathrm{mM})+\mathrm{CyONE}(0.045 \mathrm{mM})$ & 22 & -2 \\
5 & $\mathrm{CyOH}(0.220 \mathrm{mM})+\mathrm{AA}(0.080 \mathrm{mM})$ & 12 & -13 \\
6 & $\mathrm{CyONE}(0.059 \mathrm{mM})+\mathrm{AA}(0.091 \mathrm{mM})$ & 9 & -16 \\
7 & $\begin{array}{l}\text { CyOH }(0.195 \mathrm{mM})+\mathrm{CyONE}(0.049 \mathrm{mM}) \\
+\mathrm{AA}(0.078 \mathrm{mM})\end{array}$ & 8 & -17 \\
\hline
\end{tabular}

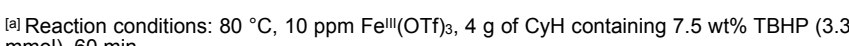
$\mathrm{mmol}), 60 \mathrm{~min}$.

\section{TOF and activation energy for $\mathrm{CyH}$ oxidation}

The reaction rate (i.e. $\mathrm{TOF}_{0}$ ) was measured at time $t=0$ in the temperature range $45-70{ }^{\circ} \mathrm{C}$ for $\mathrm{Fe}^{\mathrm{lll}}(\mathrm{OTf})_{3}$ and $\mathrm{Fe}^{\mathrm{lll}}\left(\mathrm{NTf}_{2}\right)_{3}$. In both cases, very high TOFs of $14,000 \mathrm{~h}^{-1}$ and $31,000 \mathrm{~h}^{-1}$, respectively, at $60{ }^{\circ} \mathrm{C}$, are observed. The activation energy measured from the Arrhenius plots of $\ln \left(\mathrm{TOF}_{0}\right)$ vs. $1 / \mathrm{T}$ is $145 \pm$

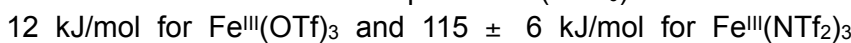

(Figure 2). At all temperatures, the $\mathrm{TOF}_{0}$ is higher for Felll $\left(\mathrm{NTf}_{2}\right)_{3}$. However, higher KA yields and TONs at $60 \mathrm{~min}$ are obtained with $\mathrm{Fe}^{\text {Ill }}(\mathrm{OTf})_{3}$ (Table 1, entries 1 and 3 ). This observation points out a faster deactivation of $\mathrm{Fe}^{\mathrm{Ill}}\left(\mathrm{NTf}_{2}\right)_{3}$ during the reaction despite its higher initial reaction rate.

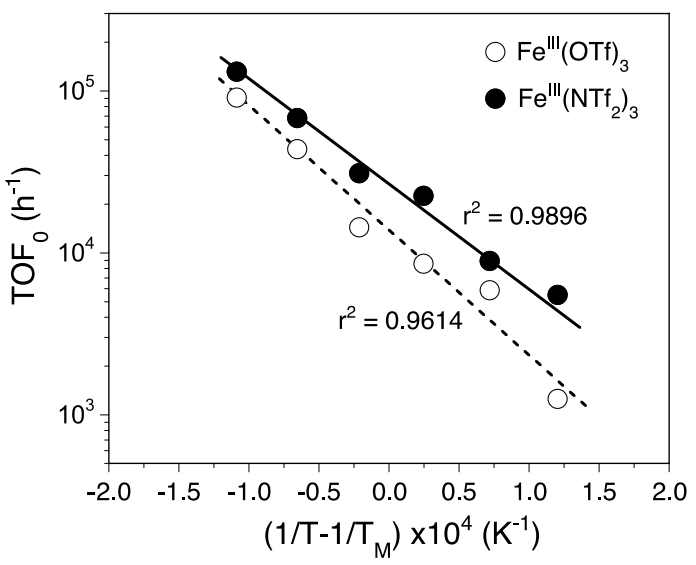

Figure 2. Arrhenius plots of $\mathrm{TOF}_{0}$ for Fe ${ }^{\text {III }}(\mathrm{OTf})_{3}$ and $\mathrm{Fe} \mathrm{e}^{\prime \prime \prime}\left(\mathrm{NTf}_{2}\right)_{3}$. TM refers to the mean temperature of the series $\left(\mathrm{T}_{\mathrm{M}}=330.7 \mathrm{~K}\right)$. Reaction conditions as in Figure 1.

\section{EPR investigation of $\mathrm{Fe}(\mathrm{III})$ coordination}

EPR is a sensitive technique for the analysis of $\mathrm{Fe}(\mathrm{III})$ species with unpaired electrons at very low concentration. In frozen solution, the $\boldsymbol{g}$-tensor component of $\mathrm{Fe}$ (III) can be measured at low- and high-spin states providing information on the symmetry and coordination sphere of the species and their evolution during the reaction. In the case of high-spin $\mathrm{Fe}(\mathrm{III})$, one should also consider the contribution of the zero-field-splitting (ZFS), which can be assessed by the so-called the $\boldsymbol{D}$ tensor. This tensor includes two components, i.e. $D$ and $E$, accounting for the intensity and anisotropy of the interaction.[25] $\mathrm{Fe}$ (II) ions, which are also paramagnetic are silent in conventional X-band (9.6 $\mathrm{GHz}$ ) spectrometers.

\section{Coordination sphere of $\mathrm{Fe}(\mathrm{III})$}

A CyH solution of Fe'll(OTf) $)_{3}$ exhibits an EPR signal at $g=2.02$ (Figure 3), which is also observed on the solid salt (Figure S1). Since the triflate ion is usually described as a weak ligand, one could reasonably expect it to be in high-spin state $(S=5 / 2)$. Indeed, Fe"l'(OTf) ${ }_{3}$ and Fe"II(NTf ( $_{3}$ have been described as highspin complexes, as also confirmed by DFT calculations (see SI, Table S1).[26] In our case, the fit of the EPR spectrum of $\mathrm{Fe}^{\text {III }}(\mathrm{OTf})_{3}$ using the Matlab ${ }^{\circledR}$ routine Easyspin is consistent with a single weakly distorted high-spin Fe center $(g=2.012, D=$ $0.01 \mathrm{~cm}^{1}, E / D=0.1$, see fitted spectrum in SI).[27] DFT calculations (see SI for Computational Details) yield a structure for Fell'(OTf) featuring three bidentate triflate anions interacting with the Fe center through two oxygen atoms (Figure 3). The metal-ligand interaction in Fe"ll(OTf) 3 is mainly ionic as confirmed by NBO analysis: both $\mathrm{Fe}$ and $\mathrm{O}$ are strongly charged (+1.7 on $\mathrm{Fe}$ and -0.9 on $\mathrm{O}$ ), and the spin is located mainly on Fe (spin density on Fe: 4.0, on O: 0.1 ). The values $g_{x}=g_{y}=g_{z}=2.01$ and $D=0.09 \mathrm{~cm}^{-1}$ were obtained using the EPR calculation module of ORCA, in good agreement with the experimental spectrum.

Coordination sphere of $\mathrm{Fe}(\mathrm{III})$ in the presence of $\mathrm{CyOH}$ and CyONE

As pointed out above, CyONE and $\mathrm{CyOH}$ are potential ligands to $\mathrm{Fe}(\mathrm{III})$, but showing a contrasting effect on the catalytic activity: 
CyONE seems to promote deactivation, whereas $\mathrm{CyOH}$ enhances the activity. To gain more insight into the coordination ability of CyONE and $\mathrm{CyOH}$ on the $\mathrm{Fe}(\mathrm{III})$ centers, a dedicated EPR study was performed.

The addition of CyONE to a CyH solution of Fell'(OTf) 3 (10 $\mathrm{mM}$ ) does not alter the EPR signal (Figure 4, Figure S2). This result is rather unexpected, since ketones should interact with $\mathrm{Fe}(\mathrm{III})$, generating a Lewis adduct. Indeed, the Gibbs free energies of coordination computed by DFT strongly support this idea (Table 5): the most stable adduct between Fell'(OTf) 3 and CyONE, i.e. mer-Fell'(OTf $)_{3}(\mathrm{CyONE})_{3}$, is favored by $-134 \mathrm{~kJ}$ $\mathrm{mol}^{-1}$. However, the electronic structure of mer$\mathrm{Fe}^{\text {III }}(\mathrm{OTf})_{3}(\mathrm{CyONE})_{3}$ is very similar to that of $\mathrm{Fe} \mathrm{el}^{\mathrm{II}}(\mathrm{OTf})_{3}$, resulting in almost the same EPR spectrum (Figure 4, blue and red curves). A high-spin, highly charged $\mathrm{Fe}(\mathrm{III})$ center $(+1.8)$ is observed with a spin mainly located on Fe (spin density $=4.0$ ). This center is prone to interact with negatively charged oxygen atoms (O of OTf -1.0, $O$ of CyONE -0.6). Since the partial charge is slightly lower on the CyONE oxygen atom, the Fe-O bond is slightly longer compared to the $\mathrm{Fe}-\mathrm{O}$ bond generated with the $\mathrm{O}$ atoms of triflates (2.11 $\AA$ vs $1.94 \AA$ ). Accordingly, the adduct geometry still approaches a slightly distorted octahedron. As the coordination of CyONE has little impact on the electronic density of $\mathrm{Fe}$, no relevant difference is expected in the EPR spectrum. Indeed, the parameters calculated by DFT are close to the previous ones: $g=2.01$ and $D=0.06 \mathrm{~cm}^{1}$.
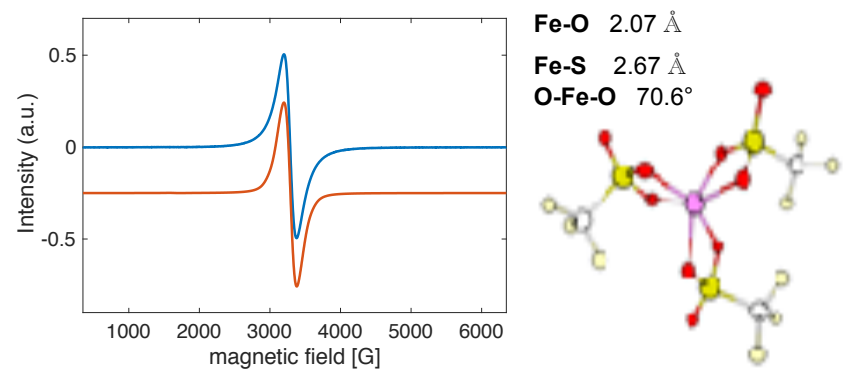

Figure 3. Experimental (blue) and fitted (orange) EPR spectra at $110 \mathrm{~K}$ of $\mathrm{Fe}^{\mathrm{ll}}(\mathrm{OTf})_{3}$ in CyH (10 mM).
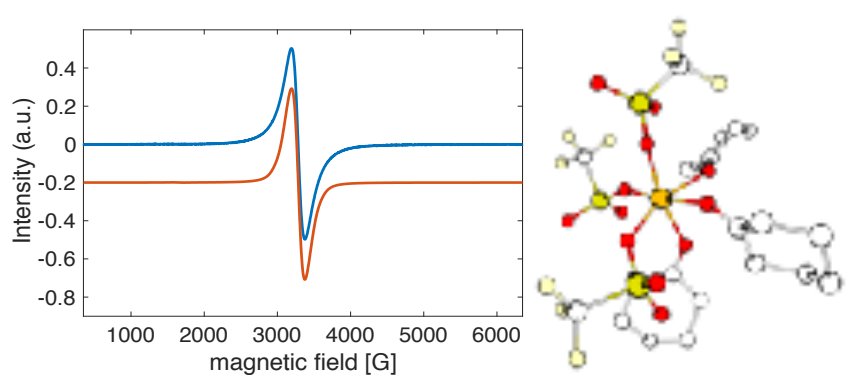

Figure 4. Experimental (blue) and fitted (red) EPR spectra at $110 \mathrm{~K}$ of $\mathrm{Fe}^{\text {III }}(\mathrm{OTf})_{3}(10 \mathrm{mM})$ in $\mathrm{CyH}$ in the presence of CyONE (10 equiv).

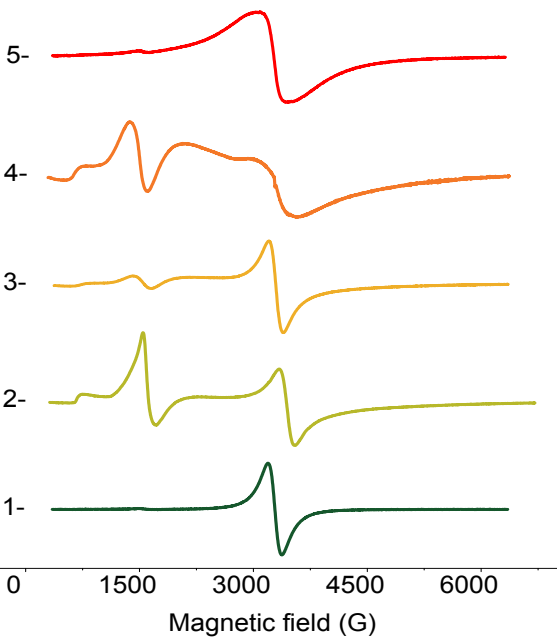

Figure 5. EPR spectra at $110 \mathrm{~K}$ of Fell'(OTf) $)_{3}(10 \mathrm{mM})$ in $\mathrm{CyH}$ in the presence of: (1) $\mathrm{CyOH}$ (3 equiv), (2) $\mathrm{CyOH}$ (10 equiv), (3) $\mathrm{CyONa}$ (1 equiv), (4) $\mathrm{CyOH}$ (10 equiv, after 1 night), and (5) CyONa (10 equiv).

Table 5. DFT-calculated enthalpy $\left(\Delta H, \mathrm{~kJ} \mathrm{~mol}^{-1}\right)$ and Gibbs free energy at 25 ${ }^{\circ} \mathrm{C}\left(\Delta G, \mathrm{~kJ} \mathrm{~mol}^{-1}\right)$ of high spin complexes resulting from the coordination of $\mathrm{CyOH}$ and CyONE to Felll(OTf)

\begin{tabular}{|c|c|c|c|c|c|}
\hline Species & $\begin{array}{c}\Delta G^{[a]} \\
\left(\mathrm{kJ}^{-1}\right)\end{array}$ & $\begin{array}{c}\Delta H^{[a]} \\
\underset{\left.\mathrm{mol}^{-1}\right)}{\mathrm{k}} \mathrm{J}\end{array}$ & $g$ & $|D|$ & $E / D$ \\
\hline $\mathrm{Fe}(\mathrm{OTf})_{3}(1)$ & 0 & 0 & 2.0 & 0.087 & 0.049 \\
\hline $\mathrm{Fe}(\mathrm{OTf})_{3}(\mathrm{CyONE})(2)$ & -47.6 & -104.4 & 2.0 & 0,085 & 0.181 \\
\hline $\mathrm{Fe}(\mathrm{OTf})_{3}(\mathrm{CyONE})_{2}(\mathbf{3})$ & -90.8 & -214.5 & $\begin{array}{c}2.0 \\
1\end{array}$ & 0.078 & 0.113 \\
\hline$\underset{(4)}{m e r-F e}(\mathrm{OTf})_{3}(\mathrm{CyONE})_{3}$ & -133.3 & -307.4 & $\begin{array}{c}2.0 \\
1\end{array}$ & 0.065 & 0.152 \\
\hline fac- $\mathrm{Fe}(\mathrm{OTf})_{3}(\mathrm{CyONE})_{3}(\mathbf{5})$ & -98.9 & -276.0 & $\begin{array}{c}2.0 \\
1\end{array}$ & 0.050 & 0.291 \\
\hline $\left.\mathrm{Fe}(\mathrm{OTf})_{3}(\mathrm{CyOH})\right](\mathbf{6})$ & -22.6 & -89.4 & $\begin{array}{c}2.0 \\
1\end{array}$ & 0.099 & 0.320 \\
\hline $\mathrm{Fe}(\mathrm{OTf})_{3}(\mathrm{CyOH})_{2}(7)$ & -99.3 & -224.7 & 2.0 & 0.078 & 0.300 \\
\hline$m e r-\mathrm{Fe}(\mathrm{OTf})_{3}(\mathrm{CyOH})_{3}(\mathbf{8})$ & -155.8 & -338.0 & 2.0 & 0.027 & 0.305 \\
\hline $\mathrm{fac}-\mathrm{Fe}(\mathrm{OTf})_{3}(\mathrm{CyOH})_{3}(\mathbf{9})$ & -93.7 & -284.4 & 2.0 & 0.066 & 0.095 \\
\hline $\mathrm{Fe}(\mathrm{OTf})_{2}(\mathrm{CyO})(\mathbf{1 0})$ & -19.8 & -67.1 & 2.0 & 0.403 & 0.212 \\
\hline $\begin{array}{l}\mathrm{Fe}(\mathrm{OTf})_{2}(\mathrm{CyOH})(\mathrm{CyO}) \\
(11)\end{array}$ & -44.8 & -151.7 & $\begin{array}{c}2.0 \\
1\end{array}$ & 0.377 & 0.065 \\
\hline $\begin{array}{l}\mathrm{Fe}(\mathrm{OTf})_{2}(\mathrm{CyOH})_{2}(\mathrm{CyO}) \\
(12)\end{array}$ & -85.3 & -247.7 & $\begin{array}{c}2.0 \\
1\end{array}$ & 0.417 & 0.147 \\
\hline
\end{tabular}

[a] The enthalpy and Gibbs free energies of complex formation were calculated with respect to free Fell'(OTf) $)_{3}, \mathrm{CyOH}$ and CyONE. In the case of complexes 10 to 12, the formation of $\mathrm{CyOH}_{2}, \mathrm{OTf}$ ion pair was considered $\left(\Delta \mathrm{G}=-6.8 \mathrm{~kJ} \mathrm{~mol}^{-1}, \Delta \mathrm{H}=-61.6 \mathrm{~kJ}\right.$ mol-1), since triflic acid is less favorable.

Likewise, the addition of $\mathrm{CyOH}$ to $\mathrm{Fe}(\mathrm{OTf})_{3}$ does not modify the EPR spectrum upon addition up to 3 equiv (Figure 5-1). As for CyONE, DFT calculations confirm that simple coordination of $\mathrm{CyOH}$ is not expected to modify the signal to an important extent (Table 5, complexes 3-5). Conversely, in the presence of an excess of $\mathrm{CyOH}$, a new signal appears at ca. $1500 \mathrm{G}$ (Figure $5-2$, Figure S3, S4), while the solubility of the salt increases significantly. The fitting of the spectrum reveals the presence of at least three different high-spin species. The first species corresponds to that described in Figure 5-1, whereas the remaining two species possess a slightly expanded $\boldsymbol{g}$-tensor 
[2.008 2.0005 2.000] and a higher zero field splitting interaction $\left(D=0.5 \mathrm{~cm}^{-1} ; E / D=0.33\right.$ and $\left.D=0.7 \mathrm{~cm}^{-1} ; E / D=0.3\right)$, being responsible for the low-field signal. From these observations, we could assume that both signals are ascribed to Fe-alkoxy complexes. Indeed, the simulated $D$ and $E$ parameters drastically increase when considering an alkoxy as ligand (Table 5, complexes 10-12).

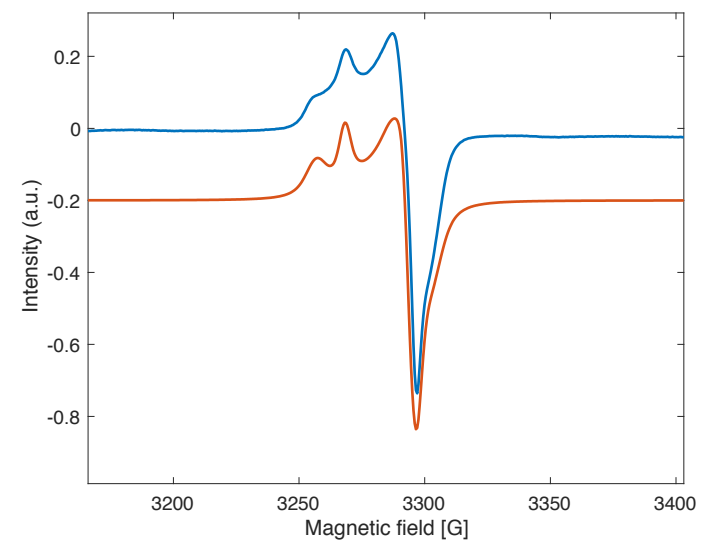

Figure 6. Experimental (blue) and fitted (red) EPR spectra at $110 \mathrm{~K}$ of $\mathrm{Fe}^{\text {III }}(\mathrm{OTf})_{3}(10 \mathrm{mM})$ in a solution of TBHP in CyH $(7.5 \mathrm{wt} \%)$.
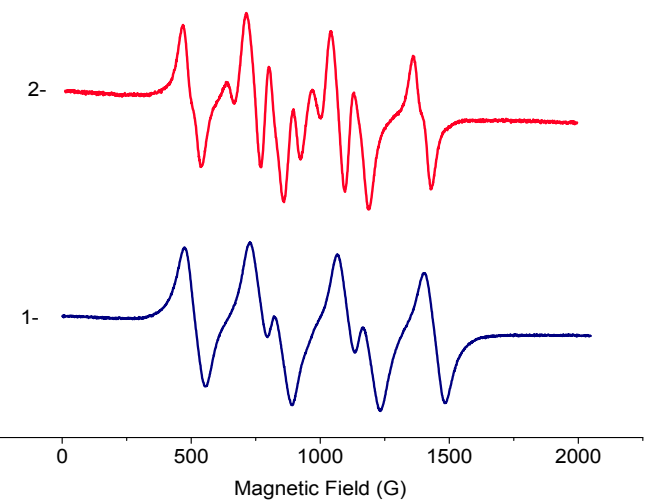

Figure 7. EPR spectra at room temperature of $\mathrm{Fe}^{\text {III }}(\mathrm{OTf})_{3}(10 \mathrm{mM})$ in a solution of TBHP in CyH (7.5 wt\%) in the presence of: (1) DMPO $(5 \mu \mathrm{L}),(2)$ DMPO $(5 \mu \mathrm{L})$ and CyONE (10 equiv).

The formation of monoalkoxy Fe species, i.e. $\left(\mathrm{Fe}(\mathrm{OTf})_{3}+(\mathrm{n}\right.$ + 2) $\mathrm{CyOH}=\mathrm{Fe}(\mathrm{OTf})_{2}(\mathrm{CyO})(\mathrm{CyOH})_{n}+\mathrm{CyOH}_{2}$.OTf, with $\mathrm{n}=0,1$ and 2 , complexes 10-12), turns out to be thermodynamically favorable, while species featuring multiple alkoxy ligands such as $\mathrm{Fe}(\mathrm{OTf})(\mathrm{CyO})_{2}(\mathrm{CyOH})_{n}$ and $\mathrm{Fe}(\mathrm{CyO})_{3}(\mathrm{CyOH})_{n}$, with $\mathrm{n}=0,1$, 2 and 3 (Table S2), are less favorable.[28] The latter complexes are all predicted to be high-spin species (see SI). The formation of iron-alkoxy species was experimentally confirmed by adding variable amounts of sodium cyclohexanate (CyONa) to $\mathrm{Fe}^{\text {III }}(\mathrm{OTf})_{3}$ (Figure 5-3, Figure S5). Indeed, after addition of 1 equiv of $\mathrm{CyONa}$, the low-field signal immediately emerges. However, under CyONa excess, only a single broad signal appears at around $g=2$ (Figure 5-5). Interestingly, a similar evolution occurs when heating at $40{ }^{\circ} \mathrm{C}$ overnight a solution of $\mathrm{Fe}^{\mathrm{Ill}}(\mathrm{OTf})_{3}$ with $\mathrm{CyOH}$ (10 equiv) in $\mathrm{CyH}$ (Figure 54). Since the formation of low-spin complexes seems unlikely with only alkoxy ligands, which is confirmed by DFT (Table S1), this observation might be explained by the formation of $\mathrm{Fe}$ (III) clusters featuring CyO- as bridging ligand. In this view, the weak dipolar interaction between localized spin momenta would broaden the signal due to unresolved coupling. [29] Indeed, these signals were successfully fitted using an increasing proportion of Gaussian part in the function (Figure S5, S6).

\section{Catalyst ageing}

The signal attributed to Fe clusters is also observed in the EPR spectrum measured after the reaction, when the catalyst is supposed to be deactivated (Figure S7). Besides the above mentioned broad signal,[30] the spectrum can be decomposed into a mixture of high-spin complexes with high ZFS interaction $\left(D=0.6 \mathrm{~cm}^{-1} E / D=0.33\right.$, and $\left.D=0.7 \mathrm{~cm}^{-1}, E / D=0.21\right)$. All the signals may be attributed to alkoxy or hydroxy Fe complexes. Overall, $\mathrm{CyOH}$ is expected to solubilize the salt, but in excess may inhibit the Fe centers.

\section{Reaction intermediates and proposed mechanism}

When TBHP is added to a solution of $\mathrm{Fe}^{\text {III }}(\mathrm{OTf})_{3}$ in $\mathrm{CyH}$, the signal ascribed to $\mathrm{Fe}(\mathrm{III})$ vanishes and only sharp signals at $\boldsymbol{g}=$ [2.024 2.009 2.007] and $\boldsymbol{g}=\left[\begin{array}{lll}2.031 & 2.011 & 2.003\end{array}\right]$ are visible (Figure 6, Figure S8). These signals are characteristic of the superoxide radical $\mathrm{O}_{2}^{\circ}$-, either free or stabilized on an EPR-silent

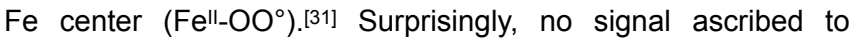
$\mathrm{Fe}^{\mathrm{lll}}(\mathrm{OOtBu})$ is observed.[5c] Radical trapping experiments were also carried out using 5,5-dimethyl-1-pyrroline N-oxide (DMPO) (Figure 7).[32] Under standard reaction conditions, a single radical is observed (Figure 7-1, $S=1 / 2, g=2.004, a_{N}=13.25 \mathrm{G}$, $a_{H}=9.98,1.45 \mathrm{G}$ ), corresponding to the adduct formed between DMPO and ${ }^{\mathrm{B}} \mathrm{BuO}^{\circ}$ (or ${ }^{\mathrm{t}} \mathrm{BOO}{ }^{\circ}$ ). ${ }^{[33]}$ No traces of $\mathrm{OH}^{\circ}$, typical of Fenton-type systems, or ${ }^{\mathrm{t}} \mathrm{Bu}^{\circ}$ trapped by DMPO, are observed. The addition of CyONE (10 equiv) results in a similar signal, but less intense, while a second species appears (Figure 7-2, $S=$ $1 / 2, g=2.006, a_{N}=7 \mathrm{G}, a_{H}=3.5 \mathrm{G}$, see also Figure S9, S10) due to DMPO oxidation. ${ }^{[34]}$ This experiment reinforces the idea of Fe poisoning by CyONE.

With these results in hand and supported by the literature, we provide in the following lines a tentative list of reactions participating during $\mathrm{CyH}$ oxidation with the detected species highlighted in bold. For a critical review on Fe-peroxo catalytic mechanisms, see Barbusinsky et al.[35]

The first reaction involves the deprotonation of TBHP to yield Fe-peroxo complexes (Eq 1-2) (X = OTf-, $\mathrm{CyO}^{-}, \mathrm{OH}^{-}$or ${ }^{\mathrm{t}} \mathrm{BuOO}-$ ). Note that the coordination sphere may be completed by additional neutral ligands such as $\mathrm{CyOH}, \mathrm{CyONE}$ and $\mathrm{H}_{2} \mathrm{O}$, which, for the sake of clarity, have been omitted.

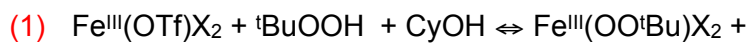
$\mathrm{CyOH}_{2}$.OTf

(2) $\mathrm{Fe}$ "l(OTf)X $+\mathrm{tBuOOH}^{\mathrm{B}} \mathrm{CyOH} \Leftrightarrow \mathrm{Fe}$ "l(OOtBu)X + $\mathrm{CyOH}_{2}$.OTf

These reactions (in equilibria) should be favored under TBHP excess, since one $\mathrm{TfOH}$ molecule is generated upon addition of $\mathrm{CyOH}$ to $\mathrm{Fe}^{\text {III }}(\mathrm{OTf})_{3}$. However, the release of free $\mathrm{TfOH}$ proved to be thermodynamically unfavorable, as inferred by DFT. Hence, we propose instead the participation of a $\mathrm{CyOH}_{2}$.OTf adduct $\left(\mathrm{X}=\mathrm{OTf}, \mathrm{n}=0, \Delta \mathrm{G}_{1}=-11 \mathrm{~kJ} \mathrm{~mol}^{-1}\right)$.

The Fell'(OOtBu) $\mathrm{X}_{2}$ complex may further evolve by oxidation of $\mathrm{Fe}(\mathrm{III})$ to $\mathrm{Fe}(\mathrm{IV})$ generating $\mathrm{tBuO}^{\circ}$ radicals (Eq 3),,[3] matching the observation by spin trapping (vide supra). Homolytic cleavage of the $\mathrm{C}-\mathrm{O}$ bond to form ${ }^{\mathrm{B}} \mathrm{Bu}^{\circ}(\mathrm{Eq} \mathrm{4-5)}$ ) is energetically unfavorable $\left(X=O T f, n=0, \Delta G_{4}=+336 \mathrm{~kJ} \mathrm{~mol}^{1}\right),{ }^{[31 \mathrm{~b}]}$ and this radical was not experimentally detected. Accordingly, the formation of superoxo radicals by this pathway is unlikely. As an 
alternative, TBHP-assisted $\mathrm{C}-\mathrm{O}$ cleavage could be driven by $\mathrm{Fe}^{\text {III }}(\mathrm{OO} \mathrm{Bu}) \mathrm{X}_{2}$ complexes according to Eq 6[31b]

$$
\begin{aligned}
& \text { (3) } \mathrm{Fe}^{\mathrm{lll}}(\mathrm{OO} \mathrm{Bu}) \mathrm{X}_{2} \rightarrow\left(\mathrm{Fe}^{\mathrm{lV}=\mathrm{O}}\right) \mathrm{X}_{2}+\mathrm{tBuO}^{\circ} \\
& \text { (4) } \mathrm{Fe}^{\prime \prime \prime}(\mathrm{OO} \mathrm{Bu}) \mathrm{X}_{2} \rightarrow \mathrm{Fe}^{\text {"II }}\left(\mathrm{OO}^{\circ}\right) \mathrm{X}_{2}+{ }^{\mathrm{t}} \mathrm{Bu}^{\circ} \\
& \text { (5) } \mathrm{Fe}^{\prime \prime}(\mathrm{OO} \mathrm{Bu}) \mathrm{X} \rightarrow \mathrm{Fe}^{\prime \prime}\left(\mathrm{OO}^{\circ}\right) \mathrm{X}+\mathrm{tBu}^{\circ} \\
& \text { (6) } \mathrm{Fe}^{\prime \prime}(\mathrm{OO} \mathrm{Bu})+{ }^{\mathrm{t}} \mathrm{BuOOH} \rightarrow \mathrm{Fe}^{\prime \prime}\left(\mathrm{OO}^{\circ}\right)+\mathrm{tBuO}^{\circ}+\mathrm{t}^{\mathrm{B} u O H}
\end{aligned}
$$

The as-generated ferryl-oxo species [i.e. $\left(\mathrm{Fe}^{\mathrm{IV}=\mathrm{O}}\right) \mathrm{X}_{2}$ ] $(\mathrm{Eq} 3)$ should be able to activate the $\mathrm{C}-\mathrm{H}$ bond in $\mathrm{CyH}(\mathrm{Eq} 7)$ and $\mathrm{CyOH}$ (Eq 8).[37] Besides, $\mathrm{FeOO}^{\circ}$ could also oxidize $\mathrm{CyH}$ (Eq 9 and Eq 10).[31b]

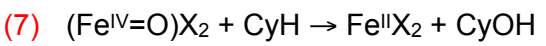

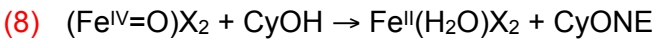

(9) $\mathrm{Fe}^{\mathrm{III}}\left(\mathrm{OO}^{\circ}\right) \mathbf{X}_{2}+\mathrm{CyH} \rightarrow\left(\mathrm{Fe}^{\mathrm{lV}=}=\mathrm{O}\right) \mathrm{X}_{2}+\mathrm{CyOH}$

(10) $\mathrm{Fe}^{\prime \prime}\left(\mathrm{OO}^{\circ}\right) \mathrm{X}+\mathrm{CyH} \rightarrow \mathrm{Fe}^{\prime \prime}\left(\mathrm{O}^{\circ}\right) \mathrm{X}+\mathrm{CyOH}$

We were curious to figure out why Fe ${ }^{\text {III }}(\mathrm{OTf})_{3}$ and $\mathrm{Fe}^{\text {III }}\left(\mathrm{NTf}_{2}\right)_{3}$ salts are highly efficient for $\mathrm{CyH}$ oxidation. Assuming that $\mathrm{C}-\mathrm{H}$ activation by a $\mathrm{Fe}(\mathrm{IV})=\mathrm{O}$ moiety is the rate-limiting step of the reaction, it may be interesting to question the very high activity of these salts. In a recent study, Sautet and coworkers reported that the activation energy for $\mathrm{C}-\mathrm{H}$ activation and the energy level of the acceptor frontier orbital of the initial $\mathrm{Fe}(\mathrm{IV})=\mathrm{O}$ intermediate $\left(\sigma^{*}\right.$ and $\pi^{*}$ for quintuplet and triplet state complexes, respectively) are linearly correlated.[38] Relying on this work, we computed the orbital energies for some plausible $\mathrm{Fe}(\mathrm{IV})=\mathrm{O}$ intermediates featuring triflate ligands and for a porphyrin-ligated $\mathrm{Fe}(\mathrm{IV})=\mathrm{O}$ as a reference (Table 6 ).

Irrespective of the ligand, the quintuplet state is favored for triflate-containing complexes, except in the case of CyO-, for which both the quintuplet and triplet states are very close in energy $\left(<1 \mathrm{~kJ} \mathrm{~mol}^{-1}\right)$. In contrast, the triplet state is favored for the porphyrin-ligated $\mathrm{Fe}(\mathrm{IV})=\mathrm{O}$. Poorly ligated triflate $\mathrm{Fe}(\mathrm{IV})=\mathrm{O}$ is the most electrophilic species with a very low $\sigma^{*}$ orbital at -5.4 eV. $\mathrm{CyOH}$ - and $\mathrm{CyONE}$-ligated triflate $\mathrm{Fe}(\mathrm{IV})=\mathrm{O}$ are predicted to be a few less active $(-4.2 \mathrm{eV}$ and $-3.9 \mathrm{eV})$. This lower electrophilicity upon coordination may account for the rapid decrease of TON along the reaction (vide infra). Coordination of the $\mathrm{CyO}-$ ligand is expected to strongly increase the $\sigma^{*}$ level $(-3.5 \mathrm{eV})$, which is in line with a potential catalyst deactivation. Finally, porphyrin-ligated $\mathrm{Fe}(\mathrm{IV})=\mathrm{O}$ exhibits the highest frontier orbitals ( $\pi^{*}:-5.6 \mathrm{eV}, \sigma^{*}=-3.3 \mathrm{eV}$ ), in agreement with the lower $\mathrm{KA}$ yield of Cl-Fell'TPP compared to that of Fe ${ }^{\text {III }}(\mathrm{OTf})_{3}$ (Table 1). Thus, the remarkable activity of Felll(OTf) $)_{3}$ for CyH oxidation may be ascribed to the higher electrophilicity of triflate-ligated $\mathrm{Fe}(\mathrm{IV})=\mathrm{O}$ species, allowing a relatively low $\mathrm{C}-\mathrm{H}$ activation barrier compared to other Fe-ligated catalysts.

FellX $\mathrm{X}_{2}$ may be re-oxidized to $\mathrm{Fe}(\mathrm{III})$ or $\mathrm{Fe}(\mathrm{IV})$ by $\mathrm{O}_{2}$ or TBHP according to Eq 11 and Eq 12

$$
\begin{aligned}
& \text { (11) } \mathrm{Fe}^{\prime \prime} \mathrm{X}_{2}+\mathrm{O}_{2} \rightarrow \mathrm{Fe}^{\| \prime \prime} \mathrm{X}_{2} \mathrm{O}_{2}{ }^{\circ} \\
& \text { (12) } \mathrm{Fe}^{\prime \prime}(\mathrm{HOO} \mathrm{Bu}) \mathrm{X}_{2} \rightarrow \mathrm{Fe}^{\prime \prime \prime}\left(\mathrm{O}^{\prime} \mathrm{Bu}\right) \mathrm{X}_{2}+\mathrm{OH}^{\circ}
\end{aligned}
$$

Table 6. Energy level of frontier orbitals (in $\mathrm{eV}$ ) of $\mathrm{S}=1$ and $\mathrm{S}=2$ spin $\mathrm{Fe}(\mathrm{IV})=\mathrm{O}$ complexes $^{\mathrm{a}}$

\begin{tabular}{lccc}
\hline Species & Spin state & $\begin{array}{c}\sigma^{*}(\mathrm{eV}), \mathrm{S}= \\
2\end{array}$ & $\pi^{\star}(\mathrm{eV}), \mathrm{S}=1$ \\
\hline $\mathrm{Fe}(\mathrm{IV}) \mathrm{O}(\mathrm{OTf})_{2}$ & 2 & -5.4 & -9.1 \\
$\mathrm{Fe}(\mathrm{IV}) \mathrm{O}(\mathrm{OTf})_{2}(\mathrm{CyOH})_{3}$ & 2 & -4.2 & -7.9 \\
$\mathrm{Fe}(\mathrm{IV}) \mathrm{O}(\mathrm{OTf})_{2}(\mathrm{CyONE})$ & 2 & -3.9 & -7.3 \\
3 & &
\end{tabular}
$\mathrm{Fe}(\mathrm{IV}) \mathrm{O}(\mathrm{CyO})_{2}(\mathrm{CyOH})$
2
2 or 1
$-3.5$
$-6.6$
$\mathrm{Fe}(\mathrm{IV}) \mathrm{O}(\mathrm{TPP})$
1
$-3.3$
$-5.6$
[a] $\mathrm{Fe}(\mathrm{IV})$ oxo complexes can be on singlet, triplet or quintuplet states. Both triplet and quintuplet states were optimized for each complex. The energy of the acceptor
orbitals (relevant to estimate the activation energy of the $\mathrm{H}$-atom transfer) are
indicated in eV. The energy of the $\pi^{\star}$ and $\sigma^{\star}$ orbitals are reported for the triplet ( $\mathrm{S}=$ 1) and quintuplet state $(S=2)$, respectively, in agreement with the conclusions in
ref [38]

However, the above reactions seem unlikely, since no traces of $\mathrm{OH}^{\circ}$ or $\mathrm{Fe}^{\mathrm{III}} \mathrm{X}_{2} \mathrm{O}_{2}{ }^{\circ}$ were experimentally detected.[39] On the

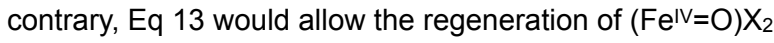

\section{(13) $\mathrm{Fe}^{\prime l}\left(\mathrm{HOO} \mathrm{Hu}^{\mathrm{B}}\right) \mathrm{X}_{2} \rightarrow\left(\mathrm{Fe}^{\mathrm{lV}}=\mathrm{O}\right) \mathrm{X}_{2}+{ }^{\mathrm{t}} \mathrm{BuOH}$}

Finally, mechanisms involving the formation of $\mathrm{CyOOH}$ and its disproportionation to $\mathrm{CyOH}$ and $\mathrm{CyONE}$ are unlikely, since the $\mathrm{A} / \mathrm{K}$ molar ratio evolves during the reaction, excluding a termination reaction according to Eq $14[5 \mathrm{c}]$

(14) $2 \mathrm{CyOOH} \rightarrow \mathrm{CyOH}+\mathrm{CyONE}$

\section{Conclusion}

Highly electrophilic high-valent iron triflate salts proved to be of high interest for the $\mathrm{C}-\mathrm{H}$ activation of cyclohexane. These salts selectively and efficiently catalyze the oxidation of cyclohexane to cyclohexanol and cyclohexone (KA oil) with very high turnover frequencies. Combined EPR spectroscopy with DFT calculations helped us to propose structures intermediates, as well as to find out possible sources of catalyst deactivation.

\section{Acknowledgements}

The authors would like to express their gratitude to Solvay, CNRS, PSL, ENS Paris, ENS de Lyon and UPMC for funding. P.A. Payard is grateful to ENS Paris Saclay for a PhD grant. WJ. Zhou gratefully acknowledges the Shanghai Youth Top-Notch Talent development program. The authors would like to thank Ilaria Ciofini, Laurent Binet and Nadia Touati (EPR network RENARD, IT CNRS 3443) from ChimieParisTech for precious assistance and advice. The authors are also grateful to Dr. J. Lai (E2P2L) and Dr C. Michel (ENS Lyon) for fruitful discussion on triflate catalysis and computation of orbital energies of $\mathrm{Fe}(\mathrm{IV})=\mathrm{O}$ intermediates, respectively.

Keywords: Iron Triflate - Oxidation - KA oil - C-H activation EPR $\cdot$ DFT $\cdot$ Cyclohexane $\cdot$ Homogeneous Catalysis

[1] M. T. Musser, Cyclohexanol and Cyclohexanone, In: Ullmann's Encyclopedia of Industrial Chemistry, 2nd ed., Wiley-VCH Verlag, Weinheim, 2002.

[2] F. Cavani, G. Strukul, Radical Chain Oxidations, In: Applied Homogeneous Catalysis with Organometallic Compounds, B. Cornils, W. A. Herrmann, M. Beller, R. Paciello eds, 3rd. edition, Wiley-VCH Verlag, Weinheim, 2018, vol 2, pp. 510-513.

[3] I. Hermans, P. A. Jacobs, J. Peeters, Chem. Eur. J. 2006, 12, 4229-4240.

[4] (a) B. Meunier, S. P. de Visser, S. Shaik, Chem. Rev. 2004, 104, 3947-3980; (b) S. P. de Visser, D. Kumar, S. Shaik, J. Inorg. Biochem. 2004, 98, 1183-1193.

[5] (a) A. L. Feig, S. J. Lippard, Chem. Rev. 1994, 94, 759-805; (b) R. Mas-Ballesté, M. Costas, T. van den Berg, L. Que, Chem Eur. J. 2006, 12, 7489-7500; (c) C. Nguyen, R. J. Guajardo, P. K. Mascharak, Inorg. Chem. 1996, 35, 6273-6281; (d) C.-W. Chiang, S. T. Kleespies, H. D. Stout, K. K. Meier, P.-Y. Li, E. L. Bominaar, L. 
Que, E. Münck, W.-Z. Lee, J. Am. Chem. Soc. 2014, 136, 10846-10849.

[6] N. M. F. Carvalho, A. Horn Jr, O. A. C. Antunes, Appl. Catal. A: Gen. 2006, 305, 140-145.

[7] H. J. H. Fenton, J. Chem. Soc., Trans. 1894, 65, 899-910.

[8] (a) M. Barbeni, C. Minero, E. Pelizzetti, E. Borgarello, N. Serpone, Chemosphere 1987, 16, 2225-2237; (b) D. L. Sedlak, A. W. Andren, Environ. Sci. Technol. 1991, 25, 777-782; (c) I. Casero, D. Sicilia, S. Rubio, D. Pérez-Bendito, Water Research 1997, 31 , 1985-1995; (d) P. L. Huston, J. J. Pignatello, Water Research 1999, 33, 1238-1246; (e) S. Nam, V. Renganathan, P. G. Tratnyek Chemosphere 2001, 45, 59-65; (f) M. Pera-Titus, V. García-Molina, M. A. Baños, J. Giménez, S. Esplugas, Applied Catal. B: Environ. 2004, 47, 219-256; (g) K. Ikehata, M. G. El-Din, J. Environ. Eng. Sci. 2006, 5, 81-135.

[9] (a) W. C. Bray, M. H. Gorin, J. Am. Chem. Soc. 1932, 54 , 2124-2125; (b) W. G. Barb, J. H. Baxendale, P. George, K. R. Hargrave, Trans. Faraday Soc. 1951, 47, 462-500; (c) P. Mignon, M. Pera-Titus, H. Chermette, Phys. Chem. Chem. Phys. 2012, 14 3766-3774.

[10] (a) J. England, C. R. Davies, M. Banaru, A. J. P. White, G. J. P. Britovsek, Adv. Synth. Catal. 2008, 350, 883-897; (b) M. Grau, A. Kyriacou, F. Cabedo Martínez, I. M. de Wispelaere, A. J. P. White, A. J. P. G. J. P. Britovsek, Dalton Trans. 2014, 43, 17108-17119.

[11] (a) D. H. R. Barton, D. Doller, Acc. Chem. Res. 1992, 25, 504-512; (b) D. H. R. Barton, Tetrahedron 1998, 54, 5805-5817.

[12] U. Schuchardt, R. Pereira, M. C. Rufo, J. Mol. Catal. A: Chem. 1998, 135, 257-262.

[13] I. Bauer, H-J. Knölker, Chem. Rev. 2015, 115, 3170-3387.

[14] O. G. Mancheño, J. Dallimore, A. Plant, C. Bolm, Org. Lett. 2009, 11, 2429-2432.

[15] (a) M. Nakanishi, A.-F. Salit, C. Bolm, Adv. Synth. Catal. 2008, 350, 1835-1840; (b) A. C. Mayer, A-F. Salit, C. Bolm, Chem. Commun. 2008, 5975-5977.

[16] (a) J-C. Choi, K. Kohno, D. Masuda, H. Yasuda, T. Sakakura, Chem. Commun. 2008, 777-779; (b) J. R. Cabrero-Antonino, A Leyva-Pérez, A. Corma, Adv. Synth. Catal. 2012, 354, 678-687; Chem, Eur. J. 2012, 18, 11107-11114; Chem, Eur. J. 2013, 19 8627-8633.

[17] P. K. Sahoo, S. S. Gawali, C. Gunanathan, ACS Omega 2018, 3, 124-136.

[18] (a) A. Stévenin, F-D. Boyer, J-M Beau, Eur. J. Org. Chem. 2012, 1699-1702; (b) A. Xolin, S. Norsikian, F-D. Boyer, J-M Beau, Eur. J. Org. Chem. 2016, 3408-3418.

[19] (a) J. Bonnamour, C. Bolm, Org. Lett. 2011, 13, 2012-2014; (b) M. A. B. Mostafa, E. D. D. Calder, S. T. Racys, A. Sutherland, Chem. Eur. J. 2017, 23, 1044-1047.

[20] C. Yao, B. Qin, H. Zhang, J. Lu, D. Wang, S. Tu, RSC Adv. 2012, 2, 3759-3764

[21] (a) B. J. Groendyke, D. I. AbuSalim, S. P. Cook, J. Am. Chem. Soc. 2016, 138, 12771-12774; (b) M. A. B. Mostafa, R. M. Bowley, D. T. Racys, M. C. Henry, A. Sutherland, J. Org. Chem. 2017, 82, 7529-7537; (c) D. T. Racys, C. E. Warrilow, S. L. Pimlott, A Sutherland, Org. Lett. 2015, 17, 4782-4785.

[22] (a) G. J. P. Britovsek, J. England, S. K. Spitzmesser, A. J. P. White, D. J. Williams, Dalton Trans. 2005, 945-955; (b) G. J. P. Britovsek, J. England, A. J. P. White, Dalton Trans. 2006, 1399-1408; (c) R. Mas-Ballesté, M. Costas, T. van den Berg, L. Que Jr, Chem. Eur. J. 2006, 12, 7489-7500; (d) J. England, R. Gondhia, L. BigorraLopez, A. R. Petersen, A. J. P. White, G. J. P. Britovsek, Dalton Trans. 2009, 5319-5334; (e) M. Lenze, E. B. Bauer, J. Mol. Catal. A: Chem. 2009, 309,117-123

[23] The TOF was computed as the slope of the kinetic curve plotting the KA yield at time $t=0$, divided by the number of Fe centers. Besides, the turnover number (TON), defined as the molar ratio between the KA formed and the number of Fe centers after 60 min reaction, was used as descriptor of catalyst deactivation.

[24] R. A. Leising, J. Kim, M. A. Perez, L. Que Jr, J. Am. Chem. Soc. 1993, 115, 9524-9530.

[25] W. R. Hagen, Biomolecular EPR Spectroscopy, 2008, CRC Press, pp 82-86.
[26] J. R. Cabrero-Antonino, A. Leyva-Pérez, A. Corma, Chem. Eur. J. 2012, 18, 11107-11114.

[27] S. Stoll, A. Schweiger, J. Magn. Res. 2006, 178, 42-55

[28] Triflic acid is a strong acid that is expected to protonate water $(\Delta G$ $\left.=-38.8 \mathrm{~kJ} \mathrm{~mol}^{-1}\right), \mathrm{CyOH}\left(\Delta G=-44.2 \mathrm{~kJ} \mathrm{~mol}^{-1}\right)$ and CyONE $(\Delta G=$ $-38.6 \mathrm{~kJ} \mathrm{~mol}^{-1}$ ) in $\mathrm{CyH}$. The protonation of $\mathrm{CyOH}$ was predicted to be the most favorable by DFT.

[29] G. Guisado-Barrios, Y. Zhang, A. M. Harkins, D. T. Richens, Inorg. Chem. Commun. 2012, 20, 81-85; A.V. Kucherov, C.N. Montreuil, T.N. Kucherova, M. Shelef, Catal. Lett. 1998, 56, 173-181.

[30] The sharp multiple between 3000 and $4000 \mathrm{G}$ is due to $\mathrm{Mn}(\mathrm{II})$ impurity resulting from $\mathrm{Mn}(\mathrm{III})$ reduction after TBHP addition, $\boldsymbol{g}=\left[\begin{array}{ll}2.032 .01 & 1.995\end{array}\right], D=0.008 \mathrm{~cm}^{-1}, E / D=0, a_{M n}=93 \mathrm{G}$, see the $\mathrm{SI}$. The presence of $\mathrm{Mn}$ has been confirmed by ICP analysis, the proportion of $\mathrm{Mn}$ in $\mathrm{Fe}(\mathrm{OTf})_{3}$ was estimated to $270 \mathrm{ppm}$.

[31] (a) M. Anpo, M. Che, B. Fubini, E. Garrone, E. Giamello, M. C. Paganini, Top. Catal., 1999, 8, 189-198; (b) W-J. Zhou, R. Wischert, K. Xue, Y-T. Zheng, B. Albela, L. Bonneviot, J-M. Clacens, F. De Campo, M. Pera-Titus, P. Wu, ACS Catal. 2014, 4, 53-62; erratum ACS Catal. 2014, 4, 1616.

[32] F. A. Villamena, EPR Spin Trapping in Reactive Species Detection in Biology, 2017, Elsevier, 2017, pp 163-202,

[33] L. D. Haire, P. H. Krygsman, E. G. Janzen, U. M. Oehler, J. Org. Chem. 1988, 53, 4535-4542.

[34] H. G. Aurich, J. Trösken, Liebigs Annal. 1971, 745, 159-163.

[35] K. Barbusinsky, Ecol. Chem. Engin., 2009, 16, 347-358.

[36] J. T. Groves, J. Inorg. Biochem. 2006, 100, 434-447.

[37] O. Pestovsky, A. Bakac, J. Am. Chem. Soc. 2004, 126, 13757-13764.

[38] (a) C. Michel, E. Jan Baerends, Inorg. Chem. 2009, 48, 3628-3638; (b) P. C. Andrikopoulos, C. Michel, S. Chouzier, P. Sautet ACS Catal., 2015, 5, 2490-2499.

[39] L. Deguillaume, M. Leriche, N. Chaumerliac, Chemosphere 2005 $60,718-724$. 
